\title{
Ammonium Oxidizing Bacteria Activity and Nitrification Rate in Oil Contaminated Wetland Soil under Remediation with Nutrient Supplements and Leguminous Plants
}

\author{
Richard C. John*, Emem S. Ntino, Joseph P. Essien \\ Department of Microbiology, University of Uyo, Uyo, Nigeria \\ Email: "richritom7@yahoo.com
}

Received 18 February 2016; accepted 25 March 2016; published 30 March 2016

Copyright (C) 2016 by authors and Scientific Research Publishing Inc.

This work is licensed under the Creative Commons Attribution International License (CC BY). http://creativecommons.org/licenses/by/4.0/

\section{Abstract}

Previous investigation on the impact of crude oil on the growth of tropical legumes and its effect on nitrogen dynamics in wetland ultisol showed that oil contamination reduced $\mathrm{N}$ uptake by plants but increased $\mathrm{N}$ accumulation in soil microbial biomass. Moreover, the presence of hydrocarbons widened the $\mathrm{C} / \mathrm{N}$ ratio in soil and led to more available $\mathrm{N}$ being immobilized by soil microorganisms. The present study was carried out to evaluate the activity of ammonium oxidizing bacteria (AOB) and their nitrification potential rate (NPR) in wetland soil under a remediation course. Mineralization studies showed that ammonium- $\mathrm{N}$ levels decreased while nitrate- $\mathrm{N}$ increased progressively in the uncontaminated soil (control) cultivated with leguminous plants (cover crops) during the 12 weeks remediation period. However, the remediated soils were affected in different ways. The experimented soil cultivated with Centrosema pubescens had higher mineral nitrogen $\left(\mathrm{NH}_{4}-\mathrm{N}, \mathrm{NO}_{3}-\mathrm{N}, \mathrm{NO}_{2}-\mathrm{N}\right.$, Total $\mathrm{N}$ and $\left.\mathrm{P}\right)$ than soil cultivated with Calopogonium mucunoides and Pueraria phaseoloides. AOB counts recorded were in the ranged, $2.25 \times 10^{2}-2.66$ $\times 10^{5}, 2.31 \times 10^{2}-2.11 \times 10^{4}$ and $4.25 \times 10^{2}-2.98 \times 10^{4}$ respectively. The highest NPR was found in uncontaminated soil (11.68 - $60.92 \mathrm{nmol} \mathrm{N} / \mathrm{g}$ dry weight soil (DWS)) followed by soil treated with poultry manure $(9.65-24.86 \mathrm{nmol} \mathrm{N} / \mathrm{g} \mathrm{DWS} / \mathrm{h}), \mathrm{NPK}(7.88-39.45 \mathrm{nmol} \mathrm{N} / \mathrm{g} \mathrm{DWS} / \mathrm{h})$ and in the oil-contaminated soil ( $0.11-1.87 \mathrm{nmol} \mathrm{N} / \mathrm{g}$ DWS/h). The relations between $\mathrm{NH}_{4}-\mathrm{N}$ concentration and NPR in soil cultivated with Centrosema $(r=0.852)$, Calopogonium $(r=0.745)$ and Pueraria $(r=$ 0.722 ) were positively significant at $95 \%$ confidence limit. Similarly the relations between AOB density and NPR for Centrosema $(r=0.654 ; P=0.05)$, Calopogonium $(r=0.588 ; P=0.05)$ and Puera-

${ }^{*}$ Corresponding author.

How to cite this paper: John, R.C., Ntino, E.S. and Essien, J.P. (2016) Ammonium Oxidizing Bacteria Activity and Nitrification Rate in Oil Contaminated Wetland Soil under Remediation with Nutrient Supplements and Leguminous Plants. Journal of Environmental Protection, 7, 545-553. http://dx.doi.org/10.4236/jep.2016.74049 
ria $(r=0.518 ; P=0.05)$ were significant. The findings imply that nitrification potential of crude oilcontaminated soil differs significantly with the nutrient amendment/treatment technique adopted for remediation. Our research has shown that treatment of uncontaminated soil with cover crops increased $A O B$ and nitrification rate. More so, contaminated soil treated with poultry manure and NPK-fertilizer, cultivated with covers crops resulted in remarkable reduction in hydrocarbons content and increased population of nitrifiers and nitrification potential rates of wetland soil over time. However, contaminated soil treated with poultry manure and cultivated with Centrosema pubescens is more effective in bioremediation of crude oil-contaminated soil.

\section{Keywords}

\section{Wetland Soil, AOB, Contamination, Nitrification, Crude Oil, Ammonium}

\section{Introduction}

Nitrogen is a key element in many compounds of plant cells and its availability for plants is an important limiting factor for crop production globally [1]. In soil, the bulk of nitrogen is present in the gaseous or organic form. However, plants use nitrogen almost entirely in the inorganic form, through biological nitrogen fixation. In this process, atmospheric nitrogen is converted to inorganic nitrogen $\left(\mathrm{NH}_{3}\right)$, and through nitrogen mineralization, organic nitrogen is converted to inorganic forms (ammonium and nitrate). Both nitrogen fixation and mineralization are brought about by the activities of soil microorganisms. In mineralization, organic nitrogen is first converted to ammonium $\left(\mathrm{NH}_{4}^{+}\right)$through the process of ammonification and through nitrification $\mathrm{NH}_{4}^{+}$is converted to nitrate $\left(\mathrm{NO}_{3}^{-}\right.$), a more mobile form. Apart from nitrification, $\mathrm{NH}_{4}^{+}$once in soil solution can be held as an exchangeable cation on negatively charged surfaces as found on some soil clay particles, lost by conversion to gaseous ammonia $\left(\mathrm{NH}_{3}\right)$ under alkaline soil conditions or assimilated by soil microorganisms and plants to supply their $\mathrm{N}$ requirements, through the process of immobilization [2]. Through immobilization, soil inorganic $\mathrm{N}$ is assimilated back into the microbial population and is tied up as organic $\mathrm{N}$, temporarily reducing the plant available $\mathrm{N}$ pool, and through nitrification $\mathrm{NH}_{4}^{+}$is converted to a more mobile form $\left(\mathrm{NO}_{3}^{-}\right)$. Thus immobilization and nitrification are vital processes that regulate plant available nitrogen in soil.

Pollution of arable lands by hydrocarbons arising from transformation and exploitation of crude oil and its refined derivatives affect soil properties in various ways. Remediation of contaminated sites is usually attained through natural attenuation by microbial activities [3] [4]. Such activities are usually enhanced by organic and inorganic nutrients amendment as well as the cultivation of cover crops such as Centrosema pubescens, Calopogonium mucunoides and Peuraria phaseoloides [5] [6]. [7] observed that addition of hydrocarbon to an uncontaminated soil stimulated immobilization of nitrogen derived from mineralization of the available organic nitrogen, leading to reduced nitrification. Nitrification, a microbial aerobic autotrophic oxidation of ammonia, is one of the processes in which ammonia is removed from the environment and one of the prominent biochemical processes in the global nitrogen $(\mathrm{N})$ cycle and in individual ecosystems. Several in vitro studies have shown that pure cultures of Nitrosomonas europaea, a ubiquitous ammonium oxidizers, also oxidizes a wide variety of hydrocarbon substrates through the action of ammonia monooxygenase the first key enzyme in the autotrophic nitrification process [8]. Such cometabolism of hydrocarbons via the ammonia monooxygenase pathway may be considered as a competitive cooxidation which reduces the rate and extent of ammonia oxidation.

The present study was designed to determine the activity of ammonium oxidizing bacteria (AOB) and their nitrification potential rate (NPR) in crude oil contaminated wetland soil under remediation course with nutrient supplements and tropical legumes.

\section{Materials and Methods}

\subsection{Physicochemical Analysis of Test Soil}

Soil samples were collected aseptically from the contaminated site and experimental boxes for physicochemical analysis. The samples were air dried and passed through a $2 \mathrm{~mm}$ sieve. Particle size distribution of the soil sam- 
ples were analyzed by combination of wet sieving and hydrometer techniques [9] using calgon as the dichromate wet oxidation methods of Walkley and Black as modified by [10]. Soil pH was determined in water using a pye Unicam pH meter [11]. Hydrocarbon content in soil was analyzed by gas chromatograph (HP5890) after extracting the soil samples with dichloromethane [12].

Mineral nitrogen was determined by an automated water analyzer (water auto-analyzer, swAAT, BLTEC, Tokyo, Japan). $20 \mathrm{~g}$ of soil sample was placed into a polypropylene centrifuge tube and tightly capped. After centrifugation at $4000 \mathrm{~g}$ for $15 \mathrm{~min}$, the supernatant was collected, filtered through $0.45 \mu \mathrm{m}$-pore-size cellulose ester filter (Advantec, Toyo Roshi Kaisha, Tokyo, Japan), and frozen immediately until analysis. $\mathrm{NH}_{4}-\mathrm{N}, \mathrm{NO}_{2}-\mathrm{N}$, $\mathrm{NO}_{3}-\mathrm{N}, \mathrm{PO}_{4}$, Total Nitrogen (TN) and Total Phosphate (TP) were analyzed using an automated water analyzer. The TN and TP concentrations were measured by peroxodisulfate oxidation [13] while $\mathrm{NH}_{4}-\mathrm{N}_{\text {concentration }}$ was determined by the method of the alkali phenolhypochlorite reaction detected photometrically at $630 \mathrm{~nm}$. $\mathrm{NO}_{2}-\mathrm{N}$ concentration was analyzed by diazotizing with sulfanilamide and coupling with N-(1-naphthyl) ethylenediamine dihydrochloride to form a highly colored azo dye and detected photometrically at $550 \mathrm{~nm}$. $\mathrm{NO}_{3}-\mathrm{N}$ was determined by the same method for $\mathrm{NO}_{2}-\mathrm{N}$ after $\mathrm{NO}_{3}$ was reduced by the cadmium reduction process. $\mathrm{PO}_{4}$ was determined by the ascorbic acid method at $800 \mathrm{~nm}$.

\subsection{Experimental Design}

Twenty litres of Bonny light crude oil was poured on each of the ten plots with dimension $4 \times 4 \mathrm{ft}$. The objective was to simulate conditions of a major spill. The plots were left undisturbed for a period of one week. After one week, the top soil (3 cm depth) of the polluted plots were removed manually, homogenized and stockpiled. Precisely $10 \mathrm{~kg}$ of the composite soil sample containing $50 \mathrm{~g} / \mathrm{kg}$ of hydrocarbons was transferred into four $2 \times 2 \mathrm{ft}$ porous-bottomed wooden boxes. All planting boxes were watered consecutively for three days with surface water obtained from the sample area. The oil treated boxes and control box were left undisturbed for a period of one week before the application of nutrient supplements (remediation methods). The period of one week was supposed to be enough for contingency plans for combating and abating the oil pollution. Thereafter, the following nutrient supplements were applied:

1) Contaminated soil treated with 200 g poultry manure,

2) Contaminated soil with 200 g NPK (15:15:15),

3) Contaminated soil without any treatment,

4) Uncontaminated soil without treatment (control soil).

All treatments except poultry manure was dissolved in distilled water and applied in liquid form to guarantee the uniform distribution within the soil medium. After nutrient application, the treated and untreated boxes were left undisturbed for four weeks, except for intermittent watering at an interval of two days. These treatments reduce the crude oil content in the contaminated soil from $50 \mathrm{~kg}^{-1}$ to $10.8,15.2$ and $48.8 \mathrm{~kg}^{-1}$ in poultry manuretreated soil, NPK-treated soil and oil-contaminated soil without nutrient supplement respectively. Thereafter, four seeds of each plant were examined to ascertain that they were similar in size before they were seeded into the wooden boxes. The plants were watered adequately on daily basis with surface water obtained from the sample area for 12 weeks to maintain a permanently wet environment and allowed to adapt and grow in vitro, forming buds and leaves. Three sets in triplicate experimental macrocosms were prepared, each for the three different species of legumes_Calopogonium mucunoides, Centrosema pubescens and Pueraria phaseoloides. Uncontaminated and contaminated soils with and without treatments were also set up to serve as controls.

\subsection{Enumeration of Ammonium-Oxidizing Bacteria (AOB) in Test Soil}

Ammonium-oxidizing bacteria were determined by the Most Probable Number (MPN) method in $1.5 \mathrm{~mL}$ sterile microtubes. The microtubes were filled with $900 \mu \mathrm{L}$ sterile medium for ammonia-oxidizing bacteria as described by [14]. The medium comprises $\left(\mathrm{NH}_{4}\right)_{2} \mathrm{SO}_{4}, 1.32 \mathrm{~g} / \mathrm{L} ; \mathrm{KH}_{2} \mathrm{PO}_{4}, 20 \mathrm{mg} / \mathrm{L} ; \mathrm{MgSO}_{4} 7 \mathrm{H}_{2} \mathrm{O}, 0.1 \mathrm{~g} / \mathrm{L}$; $\mathrm{FeCl}_{2} 6 \mathrm{H}_{2} \mathrm{O}, 0.014 \mathrm{~g} / \mathrm{L} ; \mathrm{CaCl}_{2} 2 \mathrm{H}_{2} \mathrm{O}, 0.18 \mathrm{~g} / \mathrm{L} ; \mathrm{Na}_{2} \mathrm{MO}_{4} 2 \mathrm{H}_{2} \mathrm{O}, 100: \mathrm{g} / \mathrm{L} ;$ EDTA, $1.0 \mathrm{mg} / \mathrm{L}$, phenol red, 0.002 g/L, dissolved in $1 \mathrm{~L}$ sterile water. The medium was adjusted to $\mathrm{pH} 8$ with $\mathrm{Na}_{2} \mathrm{CO}_{3}$. One gram of soil was suspended with $9 \mathrm{~mL}$ sterile water, and $100 \mu \mathrm{L}$ of the suspension was used to inoculate the microtube in triplicates, and serially (tenfold) diluted. Incubation was carried out at $28^{\circ} \mathrm{C}$ for 20 days. The tubes which exhibited the color change from red to yellow due to acid production were tested by adding three drops of a nitrite color reagent (sulfanilamide, 10 g/L; $n$-(1-naphtyl)-ethylenediamine 2HCl, 0.50 g/L; concentrated HCl, 100 mL/L). Tubes that 
exhibited a red color after addition of the reagent were scored positive for nitrite. The bacterial density was calculated by the MPN formula in Visual Basic program [15].

\subsection{Determination of Nitrification Potential Rate (NPR)}

NPR is an index of the abundance and activity of nitrifying bacteria, which indicates the ability of a unit of sediment to oxidize $\mathrm{NH}_{4}-\mathrm{N}$ (when $\mathrm{NH}_{4}-\mathrm{N}$ and $\mathrm{O}_{2}$ are not limiting) [16]. NPR was determined by the method described previously [16]-[19]. Briefly, the samples were homogenized, slurred (20.0 g of wet soil/200mL of sterile water) and placed into $300 \mathrm{~mL}$ Erlenmeyer flasks. Duplicate flasks from each depth were amended with ammonium $\left(\left(\mathrm{NH}_{4}\right)_{2} \mathrm{SO}_{4} ; 500 \mu \mathrm{M}\right)$ (Wako Pure Chemical Industries Ltd., Osaka, Japan) and sodium chlorate $\left(\mathrm{KClO}_{3} ; 10 \mathrm{mM}\right)$ (Wako Pure Chemical Industries Ltd.). Control flasks contained ammonium, sodium chlorate, and allylthiourea (ATU; $20 \mathrm{mg} / \mathrm{L}$ ) (Sigma-Aldrich, St. Louis MO, USA) [19] [20]. Flasks were capped with aluminum foil and incubated in the dark at $28^{\circ} \mathrm{C}$ with constant stirring using a magnetic stirrer at $100 \mathrm{rpm}$ for 96 h. Samples were collected at intervals over the incubation time. $\mathrm{NO}_{2}-\mathrm{N}$ was determined in interstitial waters of the slurry samples after filtering through $0.45 \mu \mathrm{m}$ cellulose ester membrane filter (Advantec, Toyo Roshi Kaisha, Japan). Since sodium chlorate is a specific inhibitor of nitrification, which blocks the oxidation of $\mathrm{NO}_{2}-\mathrm{N}$ to $\mathrm{NO}_{3}-\mathrm{N}$ [20], in the presence of $10 \mathrm{mM}$ chlorate, NPR was determined as the linear accumulation of nitrite with time [18] [19]. The linear regression analyses were done after the $\mathrm{NO}_{2}$ concentrations in all treatments were corrected by subtracting its concentration in the ATU control flash.

\section{Results and Discussion}

The physicochemical attributes of the test soils are presented in Table 1 . The sandy loamy soil was characterized with a $\mathrm{pH}$ of 6.9. The percentage of soil moisture content was $18 \%$ and soil organic matter was $65 \mathrm{~g} \cdot \mathrm{kg}^{-1}$. Contamination with hydrocarbons increased the total hydrocarbon content of the soil to $48.8 \mathrm{~g} \cdot \mathrm{kg}^{-1}$. Similarly the C:N ratio also increased because hydrocarbon is rich in carbon but deficient in nitrogen. [21] also reported increased $\mathrm{C}: \mathrm{N}$ ratio following hydrocarbon contamination of soil.

There was a reduction in the hydrocarbon content of the contaminated soils with nutrient supplement and cover crops. The hydrocarbon was reduced to 5.6 and $10.5 \mathrm{~g} \cdot \mathrm{kg}^{-1}$ in contaminated soils treated with poultry manure and NPK both cultivated with cover crops as against $46.8 \mathrm{~g} \cdot \mathrm{kg}^{-1}$ and $0.42 \mathrm{~g} \cdot \mathrm{kg}^{-1}$ recorded for the oil contaminated (without treatment) and uncontaminated soils treated with cover crops alone (which served as the control) respectively after 12 weeks. The uncontaminated soil (control) exhibited high concentration of mineral nitrogen $\left(\mathrm{NH}_{4}-\mathrm{N}, \mathrm{NO}_{2}-\mathrm{N}, \mathrm{NO}_{3}-\mathrm{N}, \mathrm{PO}_{4}\right.$, Total $\mathrm{P}$ and $\mathrm{N}$ ) except $\mathrm{NH}_{4}-\mathrm{N}$ followed by poultry manure and NPKtreated soils while the oil-contaminated soil (without treatment) had the lowest concentration of mineral nitrogen (Table 1). This implies that hydrocarbon contamination may cause available $\mathrm{N}$ to be immobilized into the microbial biomass thus reducing the availability of $\mathrm{N}$ for plant uptake. Mineralization studies showed that $\mathrm{NH}_{4}-\mathrm{N}$ levels decreased progressively in the uncontaminated (control) soil after the third week of incubation but increased progressively in oil-contaminated soil (without treatment) throughout the period (Figure 1). High $\mathrm{NH}_{4^{-}}$ $\mathrm{N}$ levels could indicate enhanced ammonification, reduced ammonium immobilization and reduced nitrification since these processes are intricately linked in soil and could influence the level of ammonium in soil [2]. The addition of nutrient supplements and the cultivation of leguminous plants (cover crops) resulted in progressively increased in $\mathrm{NO}_{3}-\mathrm{N}$ levels while reduction in $\mathrm{NO}_{3}-\mathrm{N}$ was recorded in oil-contaminated soil (without treatment) (Figure 1). Generally, there was higher $\mathrm{NO}_{3}-\mathrm{N}$ production in the uncontaminated soil cultivated with cover crops (control) than the contaminated soils with nutrient supplement indicating nitrification in soil free from contamination (Figure 1). This finding agrees with [7]. They reported that addition of hydrocarbon to an uncontaminated soil stimulated immobilization of nitrogen derived from mineralization of the available organic nitrogen, leading to decreased in nitrate production. A possible explanation for this might be a competition for ammonia monooxygenase, the first key enzyme in the autotrophic nitrification process which has been found to also cometabolise hydrocarbons [8]. This implies that reduction in nitrification contributed to the higher ammonium- $\mathrm{N}$ levels observed in the oil-contaminated soil. Nevertheless there was no significant difference in $\mathrm{NO}_{3}-\mathrm{N}$ level in samples treated with poultry manure and NPK throughout the remediation period. However, $\mathrm{NO}_{2}-\mathrm{N}$ was not detected in the oil-contaminated soil (without treatment).

In soil, the bulk of nitrogen is present in the gaseous or organic form; however, plants use nitrogen almost entirely in the inorganic form. Through biological nitrogen fixation, Atmospheric nitrogen is converted to inorganic 


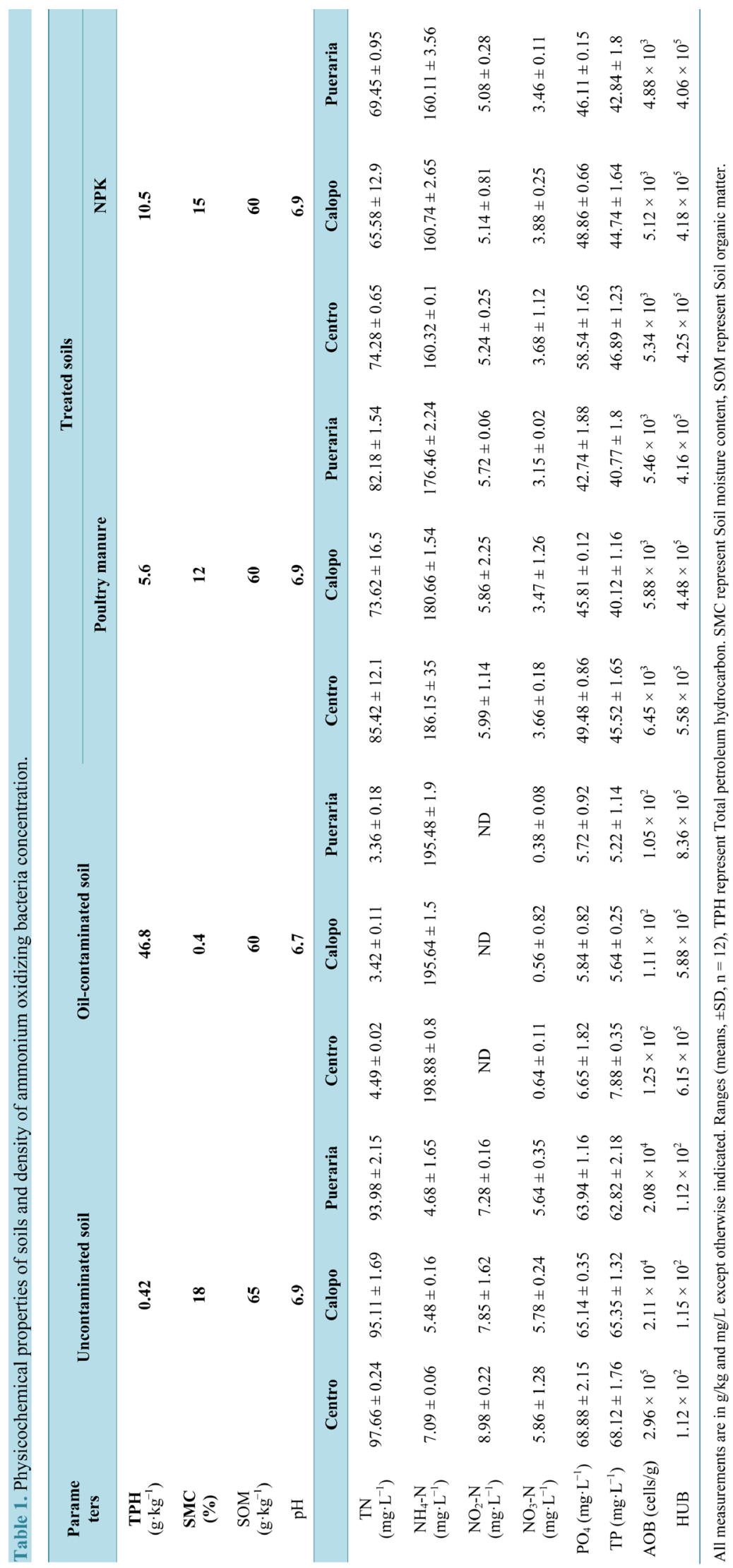




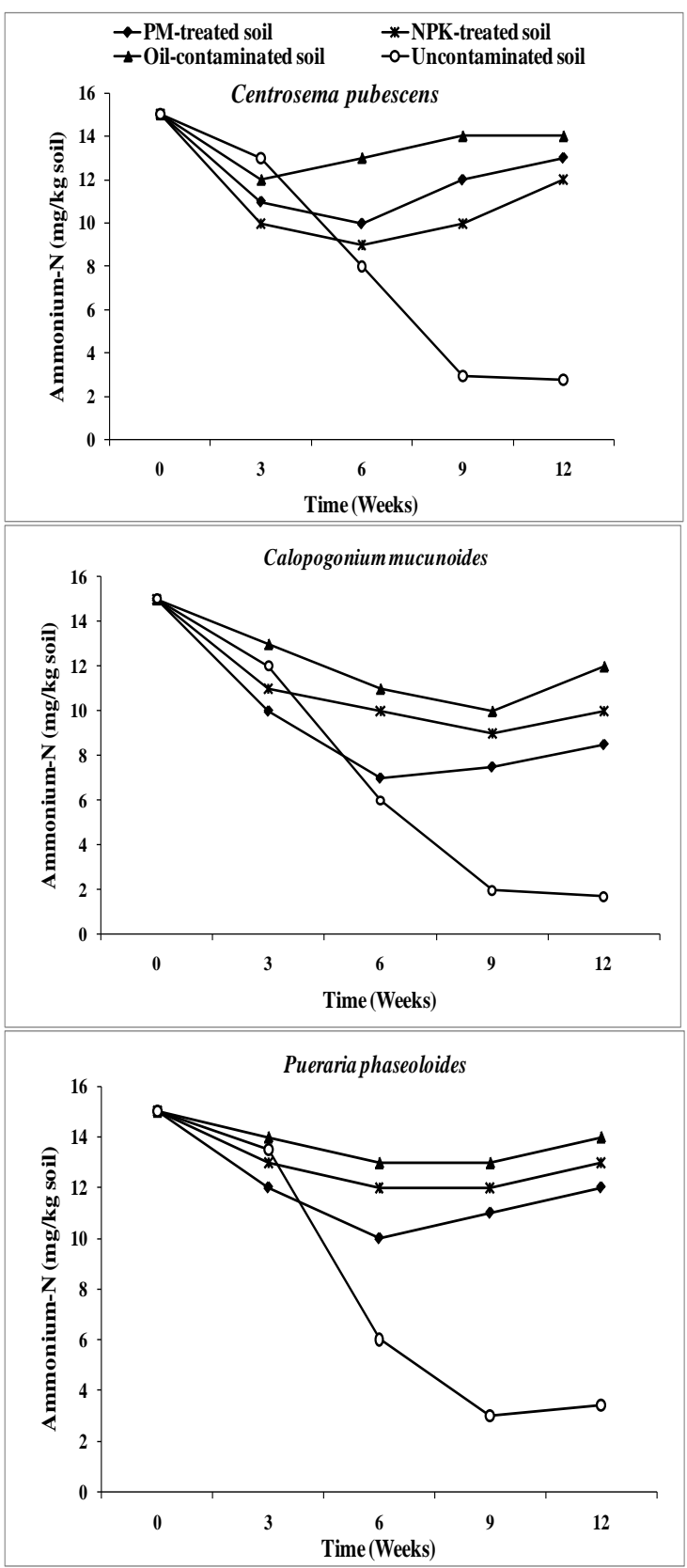

(a)
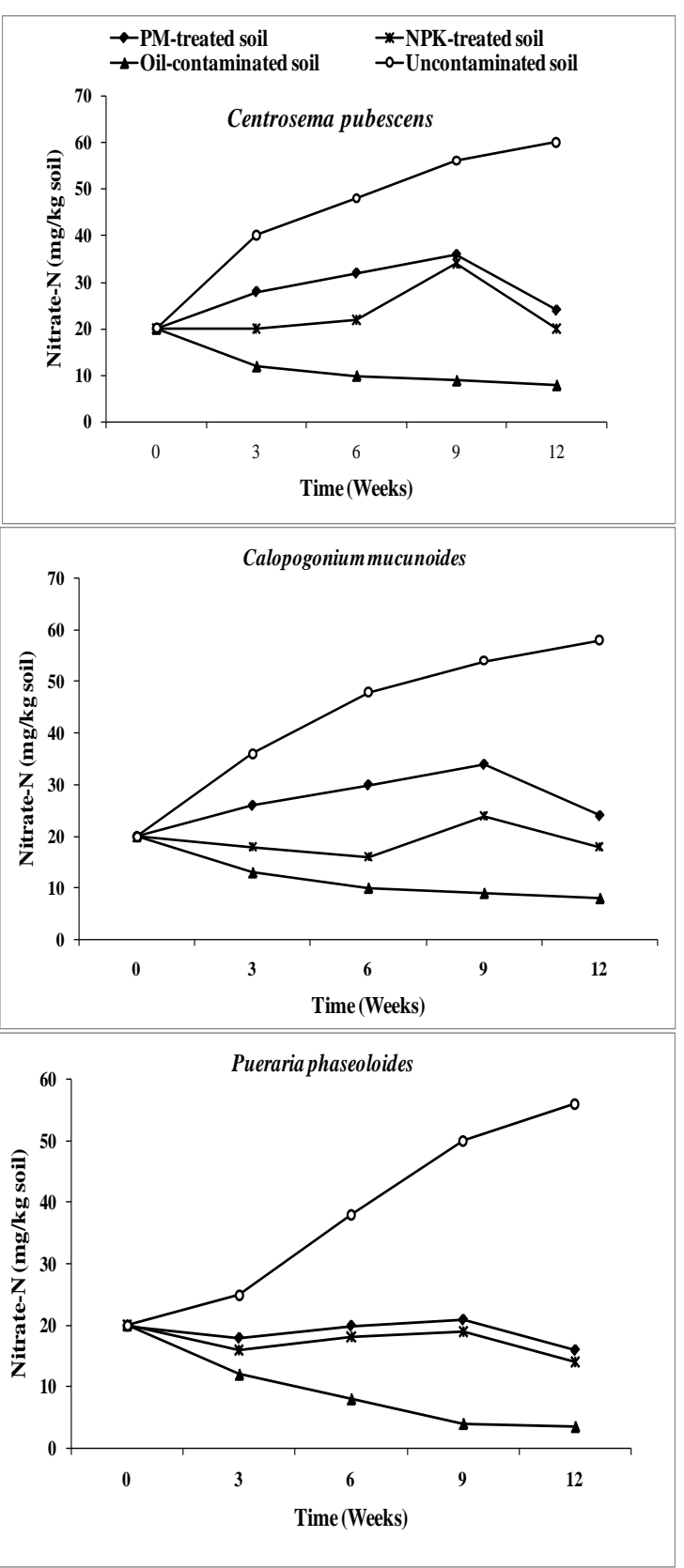

(b)

Figure 1. (a) Concentration of ammonium-N in the different treatment of contaminated and uncontaminated soils. (b) Concentration of nitrate- $\mathrm{N}$ in the different treatment of contaminated and uncontaminated soils.

nitrogen $\left(\mathrm{NH}_{3}\right)$, and through nitrogen mineralization, organic nitrogen is converted to inorganic forms (ammonium and nitrate). Both nitrogen fixation and mineralization are brought about by the activities of soil microorganisms. In this research, Uncontaminated soil cultivated with Centrosema pubescens had higher mineral nitrogen than Calopogonium mucunoides and Pueraria phaseoloides with AOB counts in the range of $2.25 \times 10^{2}-$ $2.66 \times 10^{5}, 2.31 \times 10^{2}-2.11 \times 10^{3}$ and $4.25 \times 10^{2}-2.98 \times 10^{3}$ respectively followed by poultry manure-treated soil and then NPK-treated soil (Table 1). The contaminated soils with nutrient supplement had concomitant increased in hydrocarbon-utilizing bacteria and other heterotrophic microbes, thus creating a short-term increased in biomass [22], which could have mopped up available mineral nitrogen for cell use and biomass proliferation. $\mathrm{NH}_{4}-\mathrm{N}$ was the predominant inorganic $\mathrm{N}$ source in the nutrient supplemented and control soil samples. The 
concentration of $\mathrm{NO}_{3}-\mathrm{N}$ (ammonia) was higher in the soil samples obtained from uncontaminated soil cultivated with cover crops (control) than nutrient supplemented soils with cover crops. $\mathrm{NO}_{2}-\mathrm{N}$ concentration exhibited relatively similar concentration in both poultry manure and NPK treated soil samples cultivated with Centrosema, Calopogonium and Pueraria. However, concentration of $\mathrm{NO}_{3}-\mathrm{N}$ in soil remedied with NPK-treated soil also exhibited relatively similar concentration as observed in soils treated with poultry manure (Table 1). This demonstrates the ability of both treatments in bioremediation.

In this study, nitrification was determined by measuring the accumulation of $\mathrm{NO}_{2}-\mathrm{N}$ after addition of sodium chlorate, an oxidation inhibitor of $\mathrm{NO}_{2}-\mathrm{N}-\mathrm{NO}_{3}-\mathrm{N}$. NPR measures the nitrification rate without limitation of ammonium and oxygen by amending ammonium sulfate and stirring during incubation. The accumulation of $\mathrm{NO}_{2}-\mathrm{N}$ production showed high correlations with incubation time. The co-efficient correlations ranged from $0.929-0.951,0.809-0.927,0.870-0.995$ and $0.191-0.392$ in uncontaminated soil (control), poultry manure-treated soil, NPK-treated and Oil-contaminated soil (without treatment) (Figure 2) respectively. NPRs varied significantly with the remediation approach and controls. NPRs Ranged of 11.68 - 60.92, 9.65 - 24.86, 7.88 39.45 and $0.11-1.87 \mathrm{nmol} \mathrm{N} / \mathrm{g}$ DWS/h were recorded in uncontaminated soil and poultry manure-treated soil as well as NPK-treated soil and oil-contaminated soil (without treatment) respectively. Potential nitrification has been established to be a reasonable reliable indicator in nitrifying bacteria population size [23]. Therefore, results from this study are indicative that high NPRs were found in the uncontaminated soils with cover crops alone than the supplemented soils with cover crops. In contrast, NPRs in oil-contaminated soil was very low. This may be due to insufficient dissolved oxygen which results in low density of nitrifying bacteria. However, significant potential nitrification cannot be present in absence of dissolved oxygen [24]. The effects of the three legumes on NPRs were clearly exhibited in the nutrient supplemented soils. It was apparent that the poultry
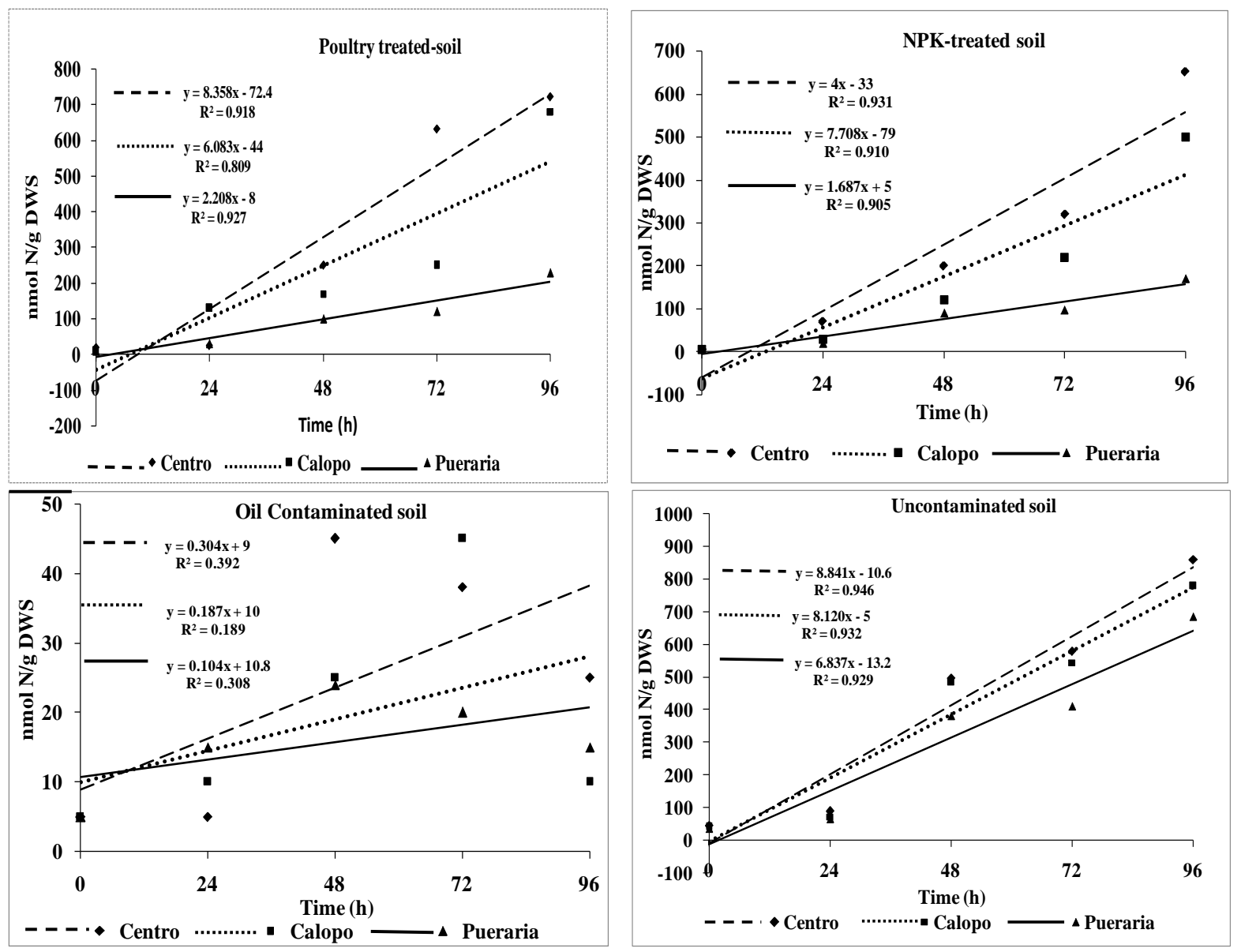

Figure 2. NPR of soil obtained from poultry manure- and NPK-treated soils, oil-contaminated and uncontaminated soil. Each experiment was done in triplicate. 
manure treated soil had relatively higher NPRs among the three legumes in the ranged of 7.18 - $19.65,6.86$ 21.88, 8.44 - $18.11 \mathrm{nmol} \mathrm{N/g} \mathrm{DWS/h} \mathrm{for} \mathrm{Centrosema,} \mathrm{Calopogonium} \mathrm{and} \mathrm{Pueraria} \mathrm{respectively.} \mathrm{Similar} \mathrm{trend}$ was recorded in NPK-treated soil. However, the highest NPR was found in the uncontaminated soil cultivated with Centrosema that had ranged of values 11.68 - 60.92. This implies that all ammonium N produced through mineralization were quickly consumed in the uncontaminated soil planted with cover crops (control) while this is not the case in contaminated soil. Hence, the effect of crude oil contamination on the abundance of AOB and nitrification rate in soil is due more on ammonium-N production than on nitrate-N production (Figure 1).

The contributions of the overall process of ammonium production and nitrate production to net $\mathrm{N}$ mineralization in the soils were estimated by assessing the relationships between ammonium-N consumption, nitrification and net mineralization rates. Results showed that for both contaminated and uncontaminated soils, the relationships between mineralization and nitrification rates were strong and positive $(1>r>0.88)$. Spearman rank correlation analysis indicated high correlation between $\mathrm{NH}_{4}-\mathrm{N}$ concentration and NPR in soil cultivated with Centrosema $(\mathrm{r}=0.852)$, Calopogonium $(\mathrm{r}=0.745)$ and Pueraria $(\mathrm{r}=0.722)$ and were positively significant at $95 \%$ confidence limit. Similarly, the relation between AOB density and NPR for Centrosema $(r=0.654 ; \mathrm{P}=0.05)$, Calopogonium ( $\mathrm{r}=0.588 ; \mathrm{P}=0.05)$ and Pueraria $(\mathrm{r}=0.518 ; \mathrm{P}=0.05$ ) were positively significant. The findings imply that nitrification potential of crude oil-contaminated soil differs significantly with the nutrient amendment/treatment technique adopted for remediation. Hence, contaminated soil treated with poultry manure and cultivated with Centrosema pubescens is highly effective in bioremediation of crude oil contaminated soil.

\section{Conclusion}

The study has shown that nitrification potential rates differ significantly between different soil treatments. The low rates of potential nitrification in contaminated soil are as a result of anoxic condition possibly resulting from increase hydrocarbon content in the soil which hindered the growth of nitrifiers. Our research has shown that treatment of uncontaminated soil with cover crops increased AOB and nitrification rate. More so, contaminated soil treated with poultry manure and NPK-fertilizer, cultivated with covers crops resulted in remarkable reduction in hydrocarbons content and increased population of nitrifiers and nitrification potential rates of wetland soil over time. However, contaminated soil treated with poultry manure and cultivated with Centrosema pubescens is highly effective in bioremediation of crude oil-contaminated soil.

\section{References}

[1] Foth, H.D. and Ellis, B.G. (1997) Soil Fertility. CRC Press, Boca Raton. In: Klute, A., Ed., Methods of Soil Analysis, Part 1. Physical and Mineralogical Methods, American Society of Agronomy, Soil Science Society of America, Madison, 383-411.

[2] Deenik, J. (2006) Nitrogen Mineralization Potential in Important Agricultural Soils of Hawaii. Soil and Crop Management, 16, 1-5.

[3] Odokuma, L.O. and Dickson, A.A. (2003) Bioremediation of a Crude Oil-Polluted Tropical Rain Forest Soil. Global Journal of Environmental Sciences, 2, 29-40.

[4] Ijah, U.J., Safiyanu, H. and Abioye, O.P. (2008) Comparative Study of Biodegradation of Crude Oil in Soil Amended with Chicken Droppings and NPK Fertilizer. Science World Journal, 3, 63-67

[5] John, R.C., Akpan, M.M., Essien, J.P. and Ikpe, D.I. (2010) Impact of Crude Oil Pollution on the Densities of Nitrifying and Denitrifying Bacteria in the Rhizosphere of Tropical Legumes Grown on Wetland Soil. Nigerian Journal of Microbiology, 24, 2088-2094.

[6] John, R.C., Akpan, M.M., Essien, J.P. and Ikpe, D.I. (2011) Fate of Nitrogen Fixing Bacteria in Crude Oil Contaminated Wetland Ultisol. Bulletin of Environmental Contamination and Toxicology, 87, 343-353. http://dx.doi.org/10.1007/s00128-011-0320-1

[7] Deni, J. and Penninckx, J. (1999) Nitrification and Autotrophic Nitrifying Bacteria in a Hydrocarbon-Polluted Soil. Applied and Environmental Microbiology, 65, 4008-4013.

[8] Hyma, M.R., Murton, I.B. and Arp, J.D. (1998) Interaction of Ammonia Monooxygenase from Nitrosomonas europaea with Alkanes, Alkenes, and Alkynes. Applied and Environmental Microbiology, 64, 3187-3190.

[9] Buurman, P., Van Langer, B. and Velthrost, E.J. (1996) Manual for Soil and Water Analysis. Backhuys Publishers, Leiden.

[10] Singh, D., Chhonkar, P.K. and Pandey, R.N. (1999) Soil, Plant \& Water Analysis-A Method Manual. IARI, New Delhi. 
[11] AOAC (2005) Methods of Soil Analysis. 12th Edition,. Association of Official Analytical Chemists, Washington DC.

[12] US Environmental Protection Agency (1981) EPA Method 413.2 in Methods for Chemical Analysis of Water and Wastes. Environmental Monitoring and Support Laboratory, Cincinnati.

[13] Ebina, J.T. and Tsutsui, S.T. (1983) Simultaneous Determination of Total Nitrogen and Total Phosphorus in Water Using Peroxodisulfate Oxidation. Water Research, 17, 1721-1726. http://dx.doi.org/10.1016/0043-1354(83)90192-6

[14] Cote, R.J. and Ghena, R.L. (1994) Nutrition and Media. In: Gerhardt, P.R., Murray, G.E., Wood, W.A. and Krieg, N.R., Eds., Methods for General and Molecular Bacteriology, American Society for Microbiology, 155-277

[15] Koch, A.L. (1994) Growth Measurement. In: Gerhardt, P.R., Murray, G.E., Wood, W.A. and Krieg, N.R., Eds., Methods for General and Molecular Bacteriology, American Society for Microbiology, 248-277.

[16] Mayer, M.S., Schaffner, L. and Kemp, W.M. (1995) Nitrification Potentials of Benthic Macrofaunal Tubes and Burrow Walls: Effects of Sediment $\mathrm{NH}_{4}{ }^{+}$and Animal Irrigation Behavior. Marine Ecology Progress Series, 121, 157-169. http://dx.doi.org/10.3354/meps121157

[17] Bianchi, M.F., Feliatra, P., Tréguer, M.A. and Vincendeau, M.J. (1997) Nitrification Rates, Ammonium and Nitrate Distribution in Upper Layers of the Water Column and in Sediments of the Indian Sector of the Southern Ocean. Deep Sea Research Part II: Topical Studies in Oceanography, 44, 1017-1032. http://dx.doi.org/10.1016/S0967-0645(96)00109-9

[18] Welsh, D.T. and Castadelli, A.G. (2004) Bacterial Nitrification activity Directly Associated with Isolated Benthic marine animals. Marine Biology, 144, 1029-1037. http://dx.doi.org/10.1007/s00227-003-1252-z

[19] Dollhopf, S.L., Hyun, J.H., Smith, A.C., Adams, H.J., Brien, S.O. and Kostka, J.E. (2005) Quantification of AmmoniaOxidizing Bacteria and Factors Controlling Nitrification in Salt Marsh Sediments. Applied and Environmental Microbiology, 71, 240-246. http://dx.doi.org/10.1128/AEM.71.1.240-246.2005

[20] Belser, L.W. and Mays, E.L. (1980) Specific Inhibition of Nitrite Oxidation by Chlorate and Its Use in Assessing Nitrification in Soils and Sediments. Applied and Environmental Microbiology, 39, 505-510.

[21] Solano-Serena, F., Marchal, R., Lebeault, J.M. and Vandecasteele, J.P. (2000) Selection of Microbial Populations Degrading Recalcitrant Hydrocarbons of Gasoline by Culture Head Space Monitoring. Letters in Applied Microbiology, 30, 19-22.

[22] Morgan, P. and Watkison, R.J. (1989) Hydrocarbon Degradation in Soils and Method of Soil Biotreatment. Critical Review in Biotechnology, 8, 305-328. http://dx.doi.org/10.3109/07388558909148196

[23] Jenkins, M.C. and Kemp, W.M. (1984) The Coupling of Nitrification and Denitrification in Two Estuarine Sediments. Limnology and Oceanography, 29, 609-619. http://dx.doi.org/10.4319/lo.1984.29.3.0609

[24] Rysgaard, S., Risgaard-Petersen, N., Sloth, N.P., Jensen, K. and Nielson, L.P. (1994) Oxygen Regulation of Nitrification and Denitrification in Sediments. Limnology and Oceanography, 39, 1643-1652. http://dx.doi.org/10.4319/lo.1994.39.7.1643 